\title{
The Landscape Creation and Integration in Design and Urban Planning of Medical Institutions
}

\author{
Irina Bulakh ${ }^{1, ~ *, ~ O l e n a ~ K o z a k o v a ², ~ M a r g a r y t a ~ D i d i c h e n k o ~}{ }^{1}$ \\ ${ }^{1}$ Department of Design Architectural Environment, Kyiv National University of Construction and Architecture, Kyiv, Ukraine \\ ${ }^{2}$ Department of Information Technologies in Architecture, Kyiv National University of Construction and Architecture, Kyiv, Ukraine

\section{Email address:} \\ irabulakh81@gmail.com (I. Bulakh), olena.kozakova.arch@gmail.com (O. Kozakova), didichenko.margo@gmail.com (M. Didichenko) \\ ${ }^{*}$ Corresponding author
}

\section{To cite this article:}

Irina Bulakh, Olena Kozakova, Margaryta Didichenko. The Landscape Creation and Integration in Design and Urban Planning of Medical Institutions. Landscape Architecture and Regional Planning. Vol. 4, No. 4, 2019, pp. 61-71. doi: 10.11648/j.larp.20190404.11

Received: September 14, 2019; Accepted: November 4, 2019; Published: November 19, 2019

\begin{abstract}
The article reveals advanced all over the world approach to architecture and urban planning design of hospitals with active usage of landscape. The newest examples of competitive and already implemented projects of medical facilities are examined, which clearly illustrate the active integration of natural and artificial reservoirs, peculiarities of natural and formation process of explicit artificial landscape in the environment of medical institutions. The article is aimed at sticking the urban planners' attention at the importance of the design and integration of the natural already exicting including landscape design approach into the hospitals' design in order to strengthen the therapeutic effect with the exterior of the medical building and the public welfare of its location.
\end{abstract}

Keywords: Architecture and Urban Planning Design, Medical Establishments, Modern Tendencies, Water, Landscape

\section{Introduction}

Exterior together with the interior and the public welfare areas of the hospital significantly affect the emotional state of a person, especially the one who is sick, stressed and agitated consequently. The architecture appearance of the hospital building and its surrounding area might enhance these patient's negative feelings or, conversely, produce feelings of confidence, peace and hope for the speed recovery. It's a real obligation of a modern architect to be aware of such an ability of emotional impact of healthcare facilities architecture. Special attention of the architect should also be paid to the development of the modern and natural environment of the hospital. The territory of any medical facility should have a minimum set of compulsory constituent elements (entrance area, pedestrian sidewalks and highways, designated parking spaces for patients and staff, and official transport). In addition to these components the territory of a medical institution, designed on the modern principles of environmental and natural design, has to be qualitative and have the detailed improvement and landscape, that might guarantee the comfort staying for different groups of patients (age, with physical disabilities, etc.). This comfort could be satisfied with the availability of landscaping and park design - all these meet a person entering a hospital and from the very beginning and thus the person is able to evaluate and get an emotional impression of the surrounding architectural and urban space of the medical building and its territory in general.

\section{Literature Review}

\subsection{The Concept of the Urban Planning Location of Medical Buildings}

Nowadays there are a lot of scientific studies focused on various aspects of architectural and urban planning of medical institutions. The issues of urban planning location of medical buildings were considered in the works of Rusina V. V. [1], Chuchmareva E. Z. [2], Podchaska-Vyshynska V. [3], Bulakh I. V. [4-7] and Didichenko M. O. [8]. A number of studies have been aimed at revealing the general principles of architectural design of medical institutions [9-11], volume and space [12-14] functional and planning [15-17] architecture methods of various range of hospital institutions 
[18-20]. General issues of architectural and urban planning objects art design, features of the composition are considered in the works of Shymko C. T. [21], Tyts A. A. [22] and Bulakh I. V. [23].

\subsection{The Architecture and Environment as a Healing Tool}

Ergonomic principles of architectural design of hospitals inclusively, were covered in the work Myronenko V. P. [24]. Numerous studies were devoted to the features and psychology of color and light perception [25-29]. The K. Day's book "Places to Live: The Architecture and Environment as a Healing Tool" is of a particular importance in this article [30]. K. Day names architecture "a dangerous tool", capable of emotionally affecting and manipulating, psychologically adjusting the state of health, mood and behavior. Taking into account the mentioned potentialities of the architectural environment in the formation of healthcare institutions, we have the opportunity to significantly increase and accelerate the process of human recovery. Architects have the opportunity not only to design facilities for the organization of treatment, but the buildings which are intended for health care and have medicinal properties themselves.

\section{Research Methods}

The article is based on a systematic research approach that assists to identify the variety of connections between the system elements with the aim of identifying potential formation and integration mechanisms of the landscape in the architectural and town-planning design of medical institutions. Based on the system analysis, the following systemic features of the territory landscape and medical buildings are revealed in the article: integrity, separation and autonomy, structure, internal interaction, interconnection of internal and external environment, emergence.

The study of the formation features and integration of the landscape while the architectural and medical institutions urban planning design was carried out on the basis of a systematic approach (considering the internal and external environment of a medical facility as an integrated system, studying the integrity of an object, identifying the variety of links' types and adjusting them into a single mechanism), complex approach (the discovery of new architectural and urban planning qualities of the environment of medical institutions by studying the object in an interdisciplinary way on the edge of different design types), a functional approach (consideration the research object as a set of the functional options; disclosing functional integrity), a historical approach (timeline research and revealing the laws of transition from one qualitative state to some another).

Depending on the tasks set, a number of research methods were used: inductive (from a single one to general), statistical, abstract-analytical (mental selection of the essential subject properties, distraction from the bits, which allows to compile a generalized image of the under study phenomenon), a comparative method (selection of similar organizations as the research objects in order to clarify the processes of change, the dynamics of the researched phenomenon). The method of historical analysis was used to summarize the architectural, urban planning and the improvement of healthcare facilities experience, the gradual introduction of landscape techniques in the formation of the external environment of medical institutions, the coherent awareness of the landscape design role and the need for its implementation as a component of the "therapeutic environment". While studying the role and influence of the "treatment environment" aesthetics the method of qualitative and quantitative analysis of the world leading countries innovative design experience was used. The methods of statistical, comparative analysis and fieldtrips were partly applied in the study to address the peculiar issues. It is recommended to use the experimental design method when formulating the landscape integration proposals for the architectural and urban planning of medical institutions in various urban conditions.

\section{The Aesthetics Problems of Medical Institutions}

\subsection{The Basis of the Problems of the Aesthetics of Medical Buildings}

The problematic of the of increasing the aesthetic level of architecture of medical institutions is obvious today. Most of the existing health care facilities in Ukraine were built in the Soviet Era of Ukrainian statehood development. During this period, the main state task was to create a powerful network of medical and preventive institutions in the shortest possible time and with less financial costs of, which had to cover the entire population of the country. In order to achieve this, the design and construction of health care facilities were carried out according to typical industrial-scale construction projects. The architecture of the medical institutions was a physical envelope for rigid medical technological processes, a functional machine devoid of unnecessary elements of beauty and aesthetics. The person in need of physical healing, during treatment, got into a temporary cell-box, aesthetic vacuum, without the possibility of visual contact with the world of the beauty (Figure 1).

\subsection{The Position of the Aesthetics of Medical Buildings in Modern Ukraine}

The mentioned problems have only intensified during Ukraine's independence. The last wave of construction of health-care facilities on the territory of Ukraine ended in the $70-80$ 's of the last century, the buildings naturally got physical and moral aging. It should be emphasized that modern urban planning regulations and rules of Ukraine are aimed at practical and technical indicators of the formation of architecture and urban environment, including the aspect of health care facilities design. 


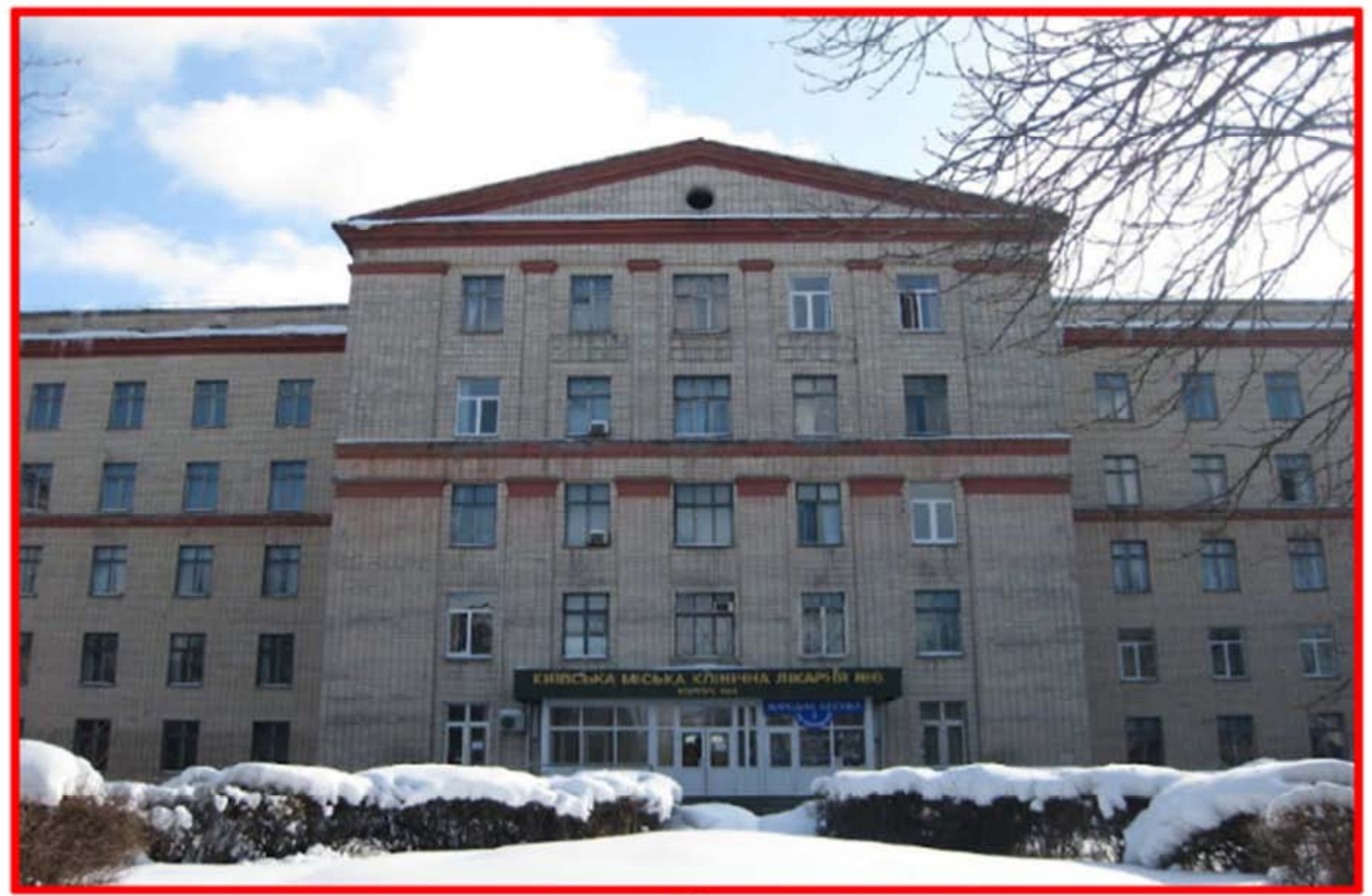

(a)

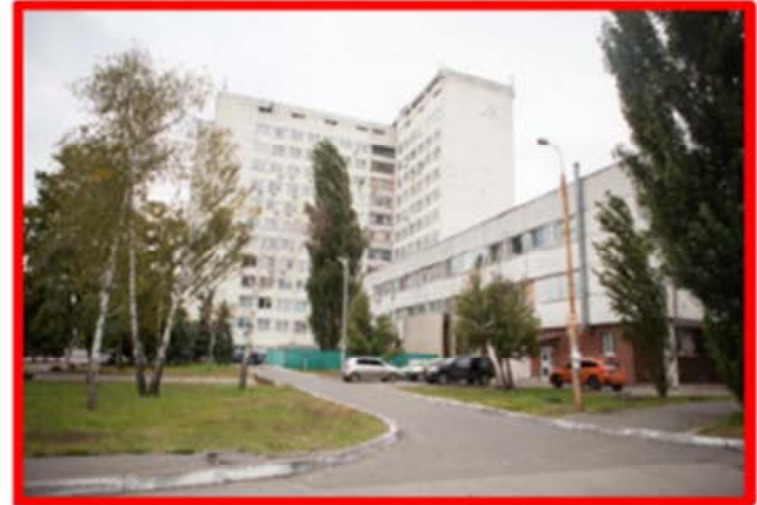

(b)

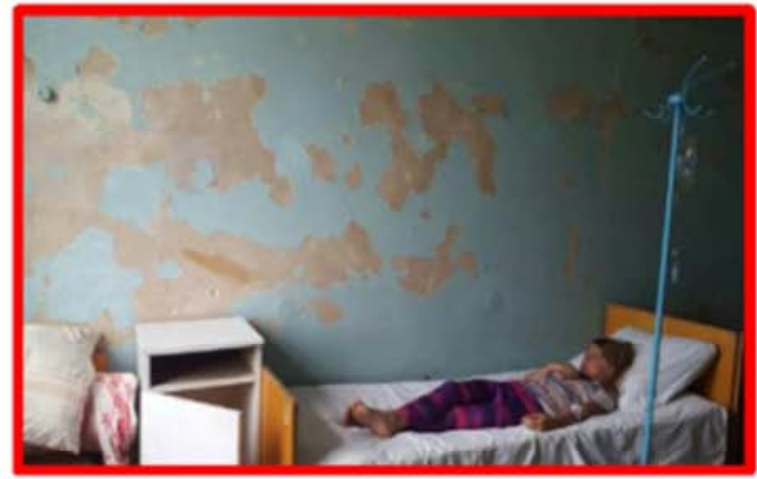

(e)

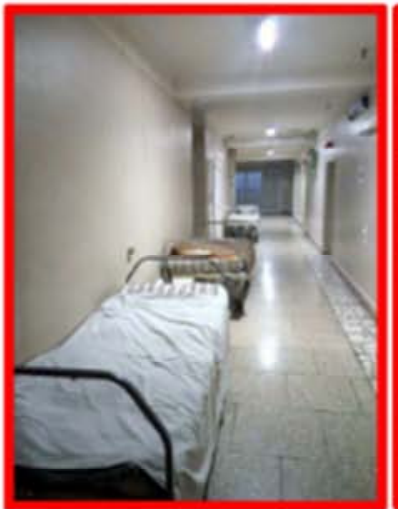

(c)

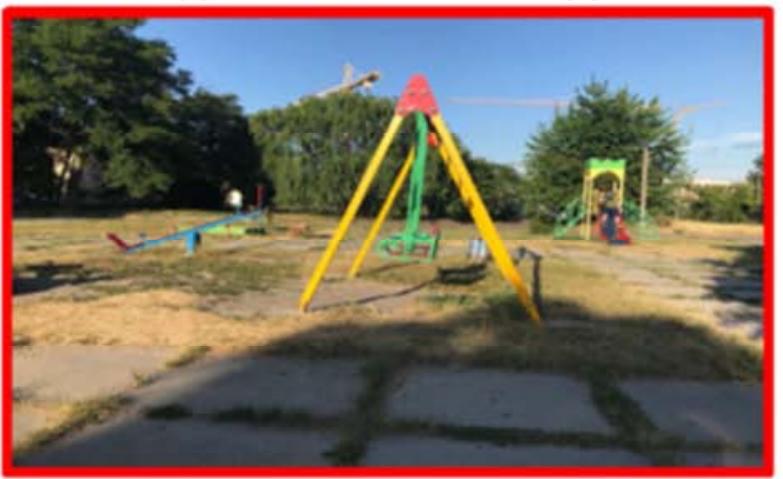

(f)

Figure 1. Ukrainian hospitals in the 21st century. (a) Kyiv City Clinical Hospital №6, Ukraine (b) Kyiv ambulance hospital, Ukraine (c) Kyiv ambulance hospital, Ukraine (d) City Clinical Hospital No 11 in Odessa, Ukraine (e) Hospital in Genichesk, Ukraine (f) Territory of Kyiv City Children's Clinical Hospital No 1. 
Issues of raising the aesthetic and philosophical level of the architectural and urban planning environment, its imagery, often depend on the professionalism of the architect, at best solved intuitively, without proper justification. The search for aesthetic expressiveness and contextuality of the medical environment is replaced by standard-typical proposals, which are not consistent with the existing urban environment, therapeutic properties and potential of the architecture. Modern healthcare facilities are gaining the character of a properly designed technical system, consequently.

\section{Landscape Integration in Architecture Design and Urban Planning of Hospitals}

The aforementioned aesthetics problems of the medical establishments are typical not only for Ukraine, but are sharply expressed and illustrated with the example of the given state. At the same time, there is a world bright experience of conceptual and competitive design, as well as the real construction and functioning of medical institutions, which together form the best practices of the architecture models of medical institutions.

These innovative examples take into account the issues of aesthetization and harmonization of the medical building with the environment, actively integrating the natural environment and, if necessary, forming their own artificial landscape with reservoirs. Such a project approach may go even a century ahead of the opinion of architects about the external and internal organization of structures intended to treat people both physically and psychologically in countries where there is a problem with the architectural and urban development of health care institutions.

Considering and analyzing the world experience of hospital design, two main trends that are absolutely absent, even in the embryonic state, in the architecture of Ukrainian medical institutions could be figured out. These trends can be conditionally characterized as the integration of landscape and reservoirs in the design of master plans of medical institutions. A lot of examples of landscape orientation in modern hospital projects all over the world already exist.

\subsection{Design of Lady Cilento Children's Hospital in Brisbane}

Thus, the giant green tree inspired the design of Lady Cilento Children's Hospital in Brisbane, a project designed by Lyons and Conrad Gargett (Figure 2). Trying to avoid the common "catwalk" and "tower" image of the hospital, the architects designed a 12-story building with two spacious atriums, rooftop terraces, and a network of branch-based interior spaces. The two atriums, symbolically referred to the trunks of surrounding trees, help visitors and staff easily navigate the pediatric center [31].
They are connected to different rooms that extend beyond the facade, forming balconies. Green and purple ribs protect the exterior of the building from direct sunlight, and the walls on the first level are covered with live plants. Inside, colored graphic images on the walls and sculptures in the form of parrots, butterflies, beetles and insects, according to the architects ideas, should distract small hospital patients.

\subsection{Design of Modern Hospital in Denmark (BIG, Herzog \& de Meuron and C. F. Moller)}

Other examples of landscape design approach in the architectural and spatial design of modern medical institutions are the finalists of the international competition for the project of the largest hospital in Denmark: BIG, Herzog \& de Meuron and C. F. Møller. The aim of this competition was to create a large-scale $124,000 \mathrm{~m}^{2} \mathrm{Nyt}$ Hospital Nordsjælland hospital complex. The site chosen for construction is the former hunting grounds: the hilly landscape with the country's largest forest area and many small lakes. The task of the architects was to unite the three existing independent hospitals into a single medical complex that would serve the area with 312,000 inhabitants. Housings had to be connected to the environment, and each of them had to be provided with the most convenient road access. The hospital is designed for 662 patients and exclusively single units [32-34].

Team of the Danish office C. F. Møller has created a project where relatively high hospital buildings are immediately visible against the background of the surrounding landscape. The "pure functionality" of this variant of the hospital meant that the largest hospital in the country should be deployed as if it was a whole city with everything needed for both the patient and the doctor. The center of the complex is defined by a hall with two circular patios in the plan. At the ground floor level, the building was annexed with a lobby covered with curved roofs, the silhouette of which echoes the smooth lines of the surrounding hills (Figure 3) [34].

The concept of the BIG architecture office involved the creation of a space capable for healing. Their variant of the hospital complex consists of eight buildings represented on the plan in the form of intersecting rings with courtyards. The architects explain their choice of this form by functional necessity: from the window of each unit it will be possible to admire the views of nature, a green courtyard or the surrounding landscape, all the rooms will be provided with sunlight, and the opportunity to walk into the yard - in the "own" garden - create conditions for communication of people. According to the authors, the fresh air, beautiful scenery and positive mood are true recovery satellites.

Hospital buildings have different heights, sometimes even falling to the ground - depending on the shape of the relief. The flat roofs are planned to be greened and the complex is almost merged with the natural environment (Figure 4) [32]. 

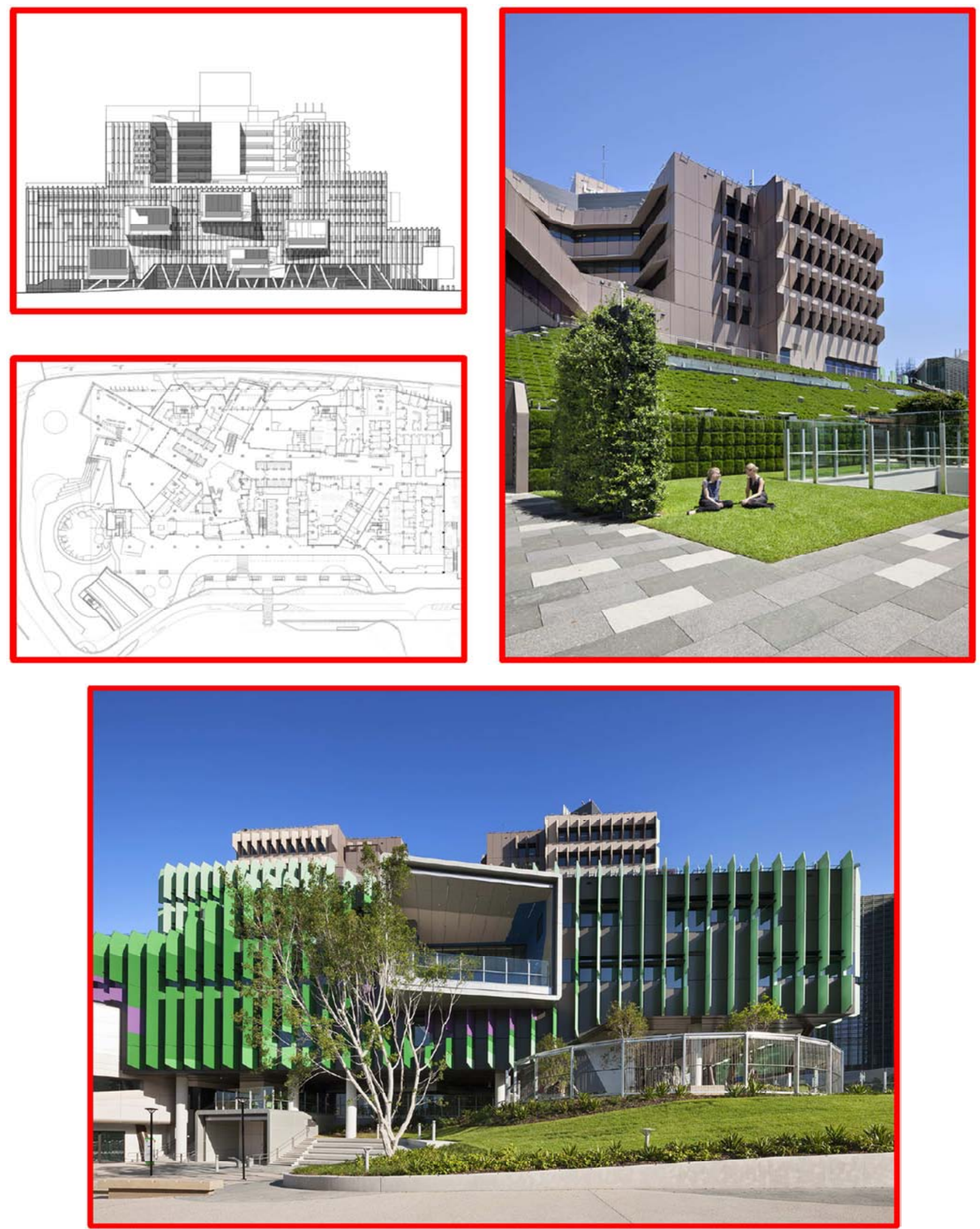

Figure 2. Children's Hospital Lady Cilento Children's Hospital in Brisbane (Australia), Lyons and Conrad Gargett office. 

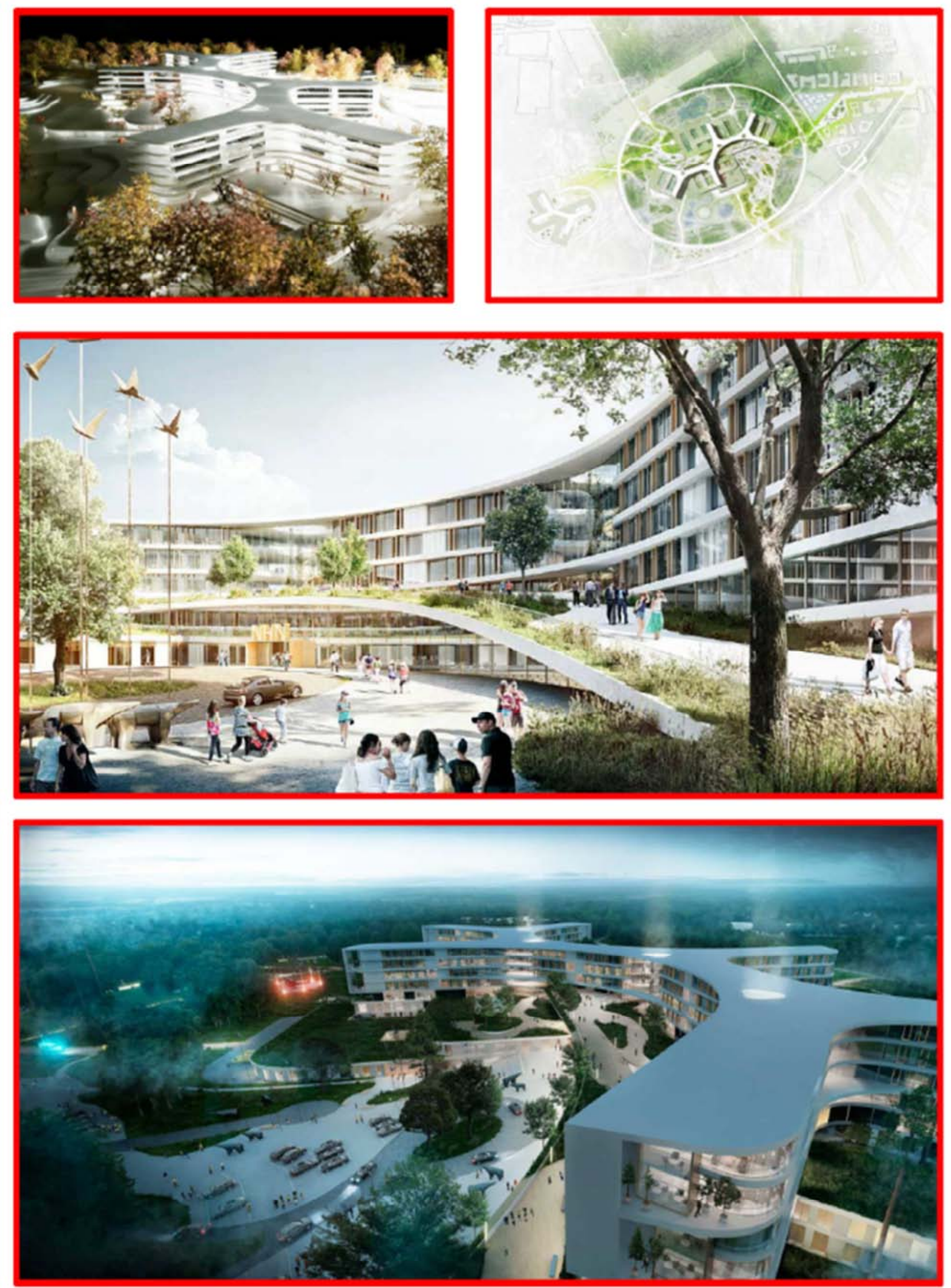

Figure 3. International competition for the hospital building in Denmark, architecture office C. F. Møller. 


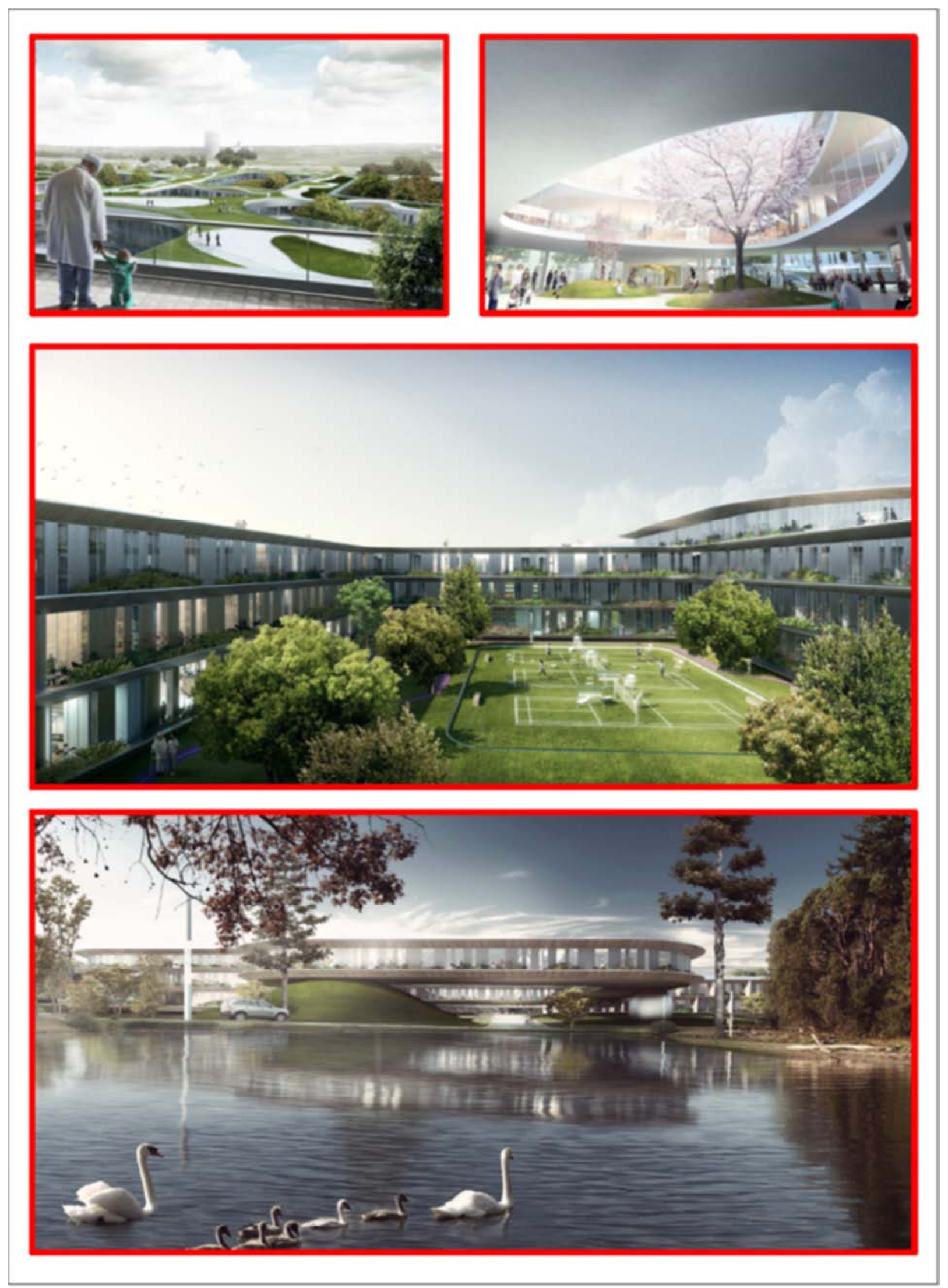

Figure 4. International competition for the hospital building in Denmark, project by the architecture office BIG.

Herzog \& de Meuron offered two- and four-story buildings implemented in the landscape. In the layout, the circle lines of the hospital complex are like the simplest living creatures, rather than the usual hospital building. This configuration of 
the hospital plan makes it possible to provide the units with daylight. The free section of the enclosures forms the courtyards and the roofs of the hospitals are green. The presented version of the project of the hospital from Herzog $\&$ de Meuron reflects the close connection of the building with the surrounding landscape, thanks to the internal courtyards and rooftop gardens, which forms the aesthetically maintained space of a modern medical facility (Figure 5) [33].

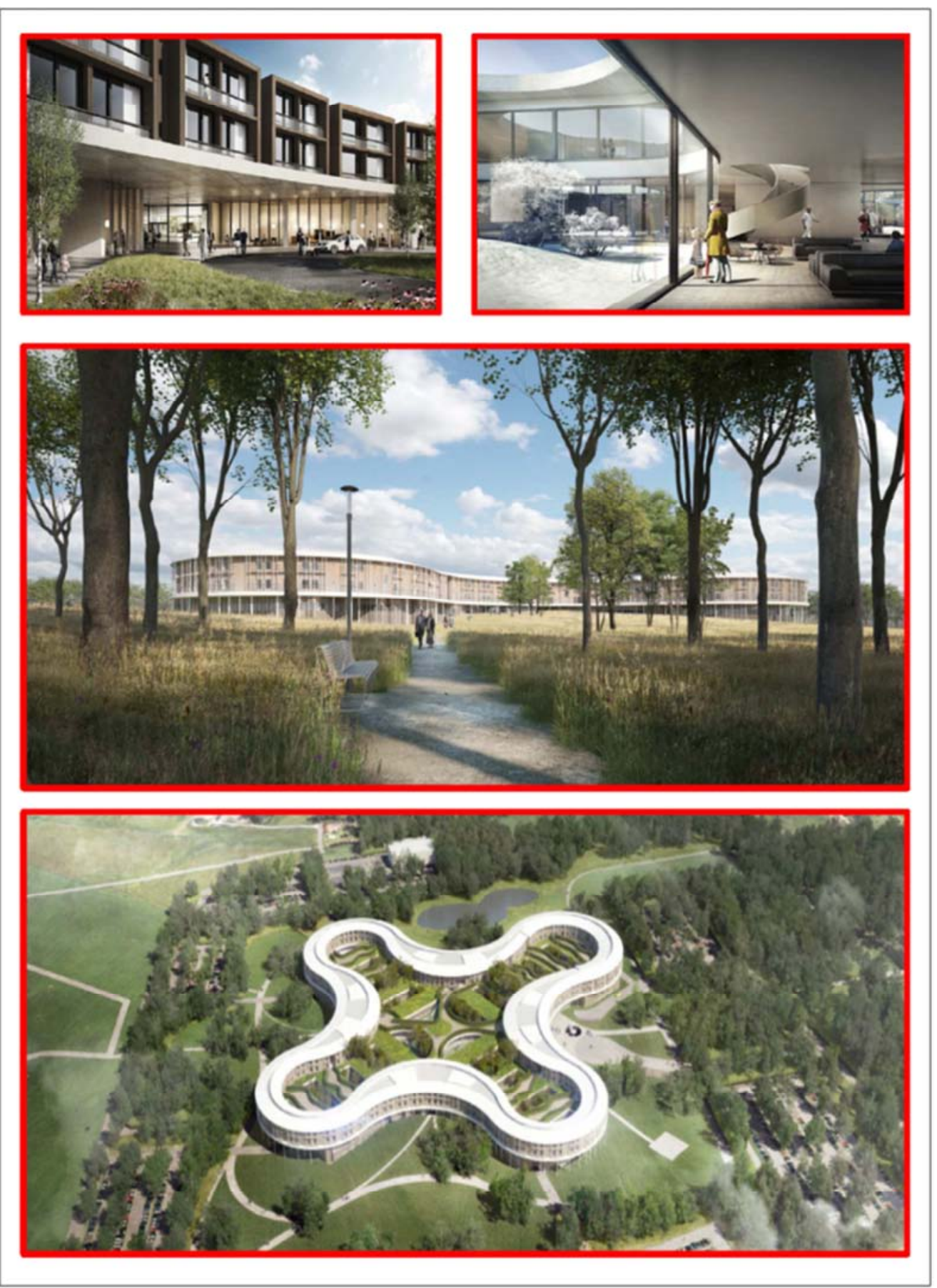

Figure 5. International competition for the hospital building in Denmark, project by the architecture office Herzog \& de Meuron.

The building of H. Hughes Medical Institute in Virginia (USA), designed in 2008 by architect Rafael Vinoly, reflects the combination of tendencies of active introduction of the surrounding terrain and placement of water in design a distinct architectural appearance of a modern medical building (Figure 6). H. Hughes Medical Institute performs the functions of a state-of-the-art medical laboratory for computational and electrophysiological examinations, robotic research, contains conference rooms, minigotels, spacious lobby, registration and rest area, private offices, treatment rooms, etc. It is envisaged to use this treatment facility for short-, medium- and long-term medical research programs, which is made possible by 
advanced 21st century biomedical research techniques. The building of the Medical Institute includes three separate functional areas, which provide advanced research and treatment, thanks to the flexible integration of the hospital into the environment, a hotel for short-term visitors, as well as a housing for long-term accommodation [35].
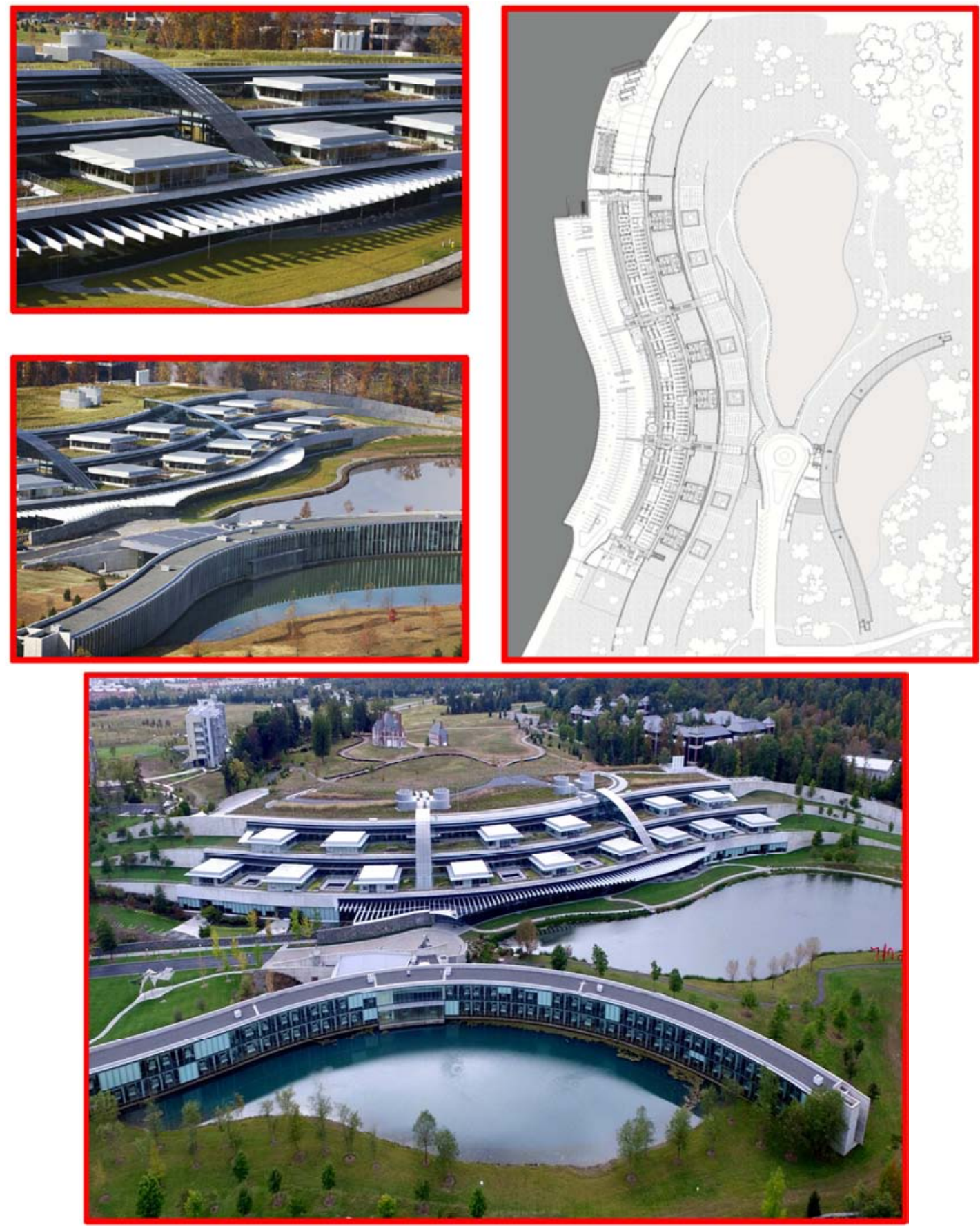

Figure 6. Howard Hughes medical institute VIRGINIA (USA), design by Rafael Vinoly architects.

\section{Conclusion}

The carried out research of the issues of landscape formation and integration in architecture and urban planning of medical establishments testified the necessity of their introduction in order to improve the aesthetics and harmonization, as well as the healing properties of medical objects. Already built contemporary innovative projects of hospital buildings, as well as references of international competitions and conceptual projects of medical buildings describe that by means of landscape design it is possible to create an individual look of the territory, to emphasize or create a natural environment, especially necessary for residents of urban metropolitan areas. Landscape approach to the formation of the master plan of the hospital allows to solve not only the issue of accommodation of basic components and elements of improvement, but also to create a park environment intended for rest, restoration of physical 
and psychological condition of sick people, which, of course, can be achieved shortly in the conditions of aesthetic and the natural environment.

\section{References}

[1] V. V. Rusin (2001). Formation of a network and types of medical institutions in modern social conditions of a big city (on the example of Poltava): abstract of the dissertation of the candidate of architecture. Kharkov, $18 \mathrm{p}$.

[2] E. Z. Chuchmareva (1998). Principles of network formation, calculation procedure and typology of outpatient facilities (using the example of the largest Soviet cities): abstract of the dissertation of the candidate of architecture. Moscow, $15 \mathrm{p}$.

[3] V. Podchaska-Wyszynska (1981). Designing of children's medical institutions. Moscow: Stroyizdat, $90 \mathrm{p}$.

[4] I. V. Bulakh, "Complex public health institutions as a complex urban development system". Colloquium-journal. Warszawa, 2019, 1 (25), pp. 4-6. DOI: 10.24411/2520-69902019-00001.

[5] G. Kovalska, I. Merylova, I. Bulakh, "Urban improvement of comprehensive schools and out of school educational establishments in Ukraine". International Journal of Innovative Technology and Exploring Engineering (IJITEE), 2019, Vol. 8, Issue 12, pp. 1765-1770. DOI: 10.35940/ijitee.L3229.1081219.

[6] I. Bulakh, V. Timokhin, G. Kovalska, I. Merylova, Y. Tretiak, "Urban environment as a phenomenon and object of architectural and urban aesthetics". Architectural Science Review, submitted for publication.

[7] I. V. Bulakh, "Dynamics of architectural and urban planning hospital system`s evolution". Science \& Technique, submitted for publication.

[8] M. O. Didichenko, "Definition and rating of the morphology landmarks of the urban planning system". Urban planning and territorial planning, 2018, Issue 68, pp. 130-139. Available: http://nbuv.gov.ua/UJRN/MTP_2018_68_19.

[9] K. Yu. Pidgirnyak, V. P. Pidgirnyak (1990). Architecture of buildings of medical institutions. Kiev: Budivelnik, 93 p.

[10] L. I. Chernyak (1964). Design of modern hospitals. Moscow: Stroyizdat, $171 \mathrm{p}$.

[11] R. W. Allen (1978). Hospital Design Manual. Moscow: Stroyizdat, $249 \mathrm{p}$.

[12] E. T. Wheeler (1972). Hospital Design. Moscow: Medicine, $24 \mathrm{p}$.

[13] C. Schirmer (2007). Hospital Architecture: Specialist Clinics \& Medical Departments. Germany, 26 p.

[14] C. Schirmer, Ph. Meuser (2007). New Hospital Building in Germany: General Hospitals and Health Centers Publisher. Germany, $34 \mathrm{p}$.

[15] H. Nickl, C. Nicki-Weller (2007). Hospital Architecture. Verlagshaus Braun, 352 p.

[16] T. A. Bulycheva (1984). Central district hospitals. Moscow: Stroyizdat. $118 \mathrm{p}$.
[17] I. V. Bulakh, "The main trends in organization of architectural environment of medical institutions". Web of Scholar. Warszawa, 2018, 5 (23), Vol. 1, pp. 59-62.

[18] I. V. Bulakh, "Common Features of Architectural Design of the Medical Purpose Building. Science \& Technique. Minsk, 2019, 18 (4), pp. 311-318. DOI: 10.21122/2227-1031-201918-4-311-318.

[19] I. V. Bulakh, "Energy efficiency use of bioclimatic facades in medical buildings". Development of modern science: the experience of European countries and prospects for Ukraine: monograph / edited by authors. 3rd ed. Riga, Latvia: Baltija Publishing, 2019, pp. 597-616.

[20] I. V. Bulakh, "New approaches to the functional planning of hospitals and entrance groups of medical institutions". Colloquium-journal. Warszawa, 2019, 9 (33), Vol. 1, pp. 4-6. DOI: 10.24411/2520-6990-2019-10213.

[21] V. T. Shimko (2004). Typological foundations of artistic design of the architectural environment. Moscow: Architecture, $104 \mathrm{p}$.

[22] A. A. Tits (1976). Fundamentals of architectural composition and design. Kiev: Vishcha shkola, 255 p.

[23] I. V. Bulakh, "Artistic-aesthetic formation and evolution of architectural and urban planning space". Science and Innovation. Kyiv, 2019, 15 (5). Available: https://doi.org/10.15407/scin15.05.038.

[24] V. P. Mironenko (1997). Ergonomic principles of architectural design: a monograph. Kharkov: Basis, 112 p.

[25] C. Padham (1978). Perception of light and color. Moscow: Nauka, $256 \mathrm{p}$.

[26] W. Brown. The psychology of color. Available: http://www.elitarium.ru/2006/06/07/psikhologija_cveta.html.

[27] B. Faber (1978). Color and Human Response. New York: Van Nostrand Reinhold, $141 \mathrm{p}$.

[28] B. Faber (1950). Color Psychology and Color Therapy: A Factual Study of the Influence of Color on Human Life. New York: McGraw-Hill, 284 p.

[29] L. Clark (1975). The Ancient Art of Color Therapy: Updated, Including Gem Therapy, Auras, and Amulets. Old Greenich, CT: Devin-Adair, 245 p.

[30] K. Day (2000). Places where the soul lives: Architecture and the environment as a remedy. Moscow: Lad'ya, $280 \mathrm{p}$.

[31] Lady Cilento Children's Hospital in Brisbane. Available: http://www.lyonsarch.com.au.

[32] Hospital in Denmark. Competition project from BIG. Available: http://www.big.dk/\#projects.

[33] Hospital in Denmark. Competition project from Herzog \& de Meuron. Available: https://www.herzogdemeuron.com/index.html.

[34] Hospital in Denmark. Competition project by C. F. Møller. Available: http://www.cfmoller.com.

[35] Howard Hughes Medical Institute in Virginia (USA). Available: http://www.e-architect.co.uk/america/howardhughes-medical-institute. 


\section{Biography}

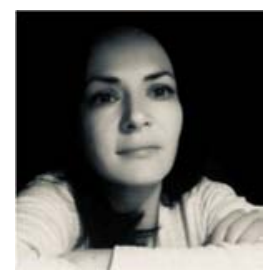

Irina Bulakh, PhD of Architecture, Doctoral studies, ORCID 0000-0002-3264-2505, Web of Science ResearcherID: V-4802-2018. Education: Master of Architecture, Department of Design architectural environment, Kyiv National University of Construction and Architecture, Kyiv, Ukraine. Place of work: Associate Professor, Department of Design architectural environment, Kyiv National University of Construction and Architecture, Kyiv, Ukraine. Publications: 84 publications, of which 75 scientific papers, 9 works of educational-methodical publications. PhD dissertation "Principles of symbolizing the architectural and artistic image of the urban environment" (2016), Doctoral dissertation "Dynamics of the city planning development of the system children treatment complexes".

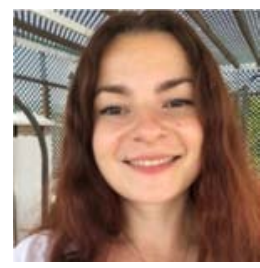

Olena Kozakova, PhD of Architecture, ORCID 0000-0003-0593-266X. Education: Master of Architecture, Department of Architecture, Kyiv National Academy of Fine Arts and Architecture, Kyiv, Ukraine. Place of work: Associate Professor, Department of information technologies in architecture, Kyiv National University of Construction and Architecture, Kyiv, Ukraine. Publications: 11 publications all in scientific papers (8 in scientific publications of Ukraine, 3 publications in scientific publications of other countries, 7 abstracts for conferences. PhD dissertation "The formation and development of traditions of Western Ukrainian hotel's architecture of XVII - XIX centuries" (2016), Field of research: architecture, urban planning, design of hotel buildings.

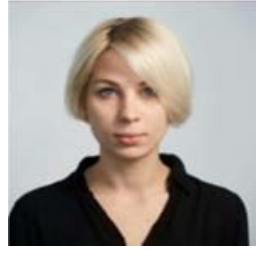

Margaryta Didichenko, Master of Architecture, PhD candidate. ORCID 0000-0002-4306-8596. Education: Master of Architecture, Department of Design architectural environment, Kyiv National University of Construction and Architecture, Kyiv, Ukraine. Place of work: Assistant, Department of Design architectural environment, Kyiv National University of Construction and Architecture, Kyiv, Ukraine. Publications: 13 scientific papers, including 6 publications in scientific periodicals of Ukraine, 1 publications in scientific periodicals of other countries, 6 abstracts for conferences. Field of research: theory of architecture, architecture, urban planning, urban morphology, historical areas development. 